\title{
ENVIRONMENTAL, SOCIAL AND GOVERNANCE (ESG) PRACTICES AND PERFORMANCE IN SHARIAH FIRMS: AGENCY OR STAKEHOLDER THEORY?
}

\author{
Lee Siew Peng ${ }^{1,2^{*}}$ and Mansor Isa ${ }^{3}$ \\ IFaculty of Accountancy and Management, Universiti Tunku Abdul Rahman, \\ Jalan Sungai Long, Bandar Sg. Long, Cheras, 43000 Kajang, Selangor, Malaysia \\ ${ }^{2}$ Oxford Centre for Islamic Studies, Oxford University, Oxford, United Kingdom \\ ${ }^{3}$ Faculty of Business and Accountancy, Universiti Malaya, \\ 50603 Kuala Lumpur, Malaysia
}

${ }^{*}$ Corresponding author: leesp@utar.edu.my, leesiewpeng99@gmail.com

\begin{abstract}
This study examines the impact of ESG (environmental, social and governance) practices on financial performance for a sample of MSCI World Islamic Index firms over the period 2010-2017. We also test whether ESG engagement should be considered an agency or stakeholder issue. Our sample consists of 461 Shariah-compliant firms from 20 countries that are included in the MSCI World Islamic Index. Firms' involvement in ESG activities is taken from the Thomson Reuters ASSET4 database. The results reveal that ESG aggregate and its individual dimensions are positively related to firm performance, which is consistent with the stakeholder theory. We do not find evidence that ESG is associated with agency problems. The findings suggest that combined ESG and Shariah screenings can increase firm value, enhance more ethical, responsible and transparent practices and thus, create new markets for potential investors.
\end{abstract}

Keywords: ESG, agency theory, stakeholder theory, Shariah-compliant

Publication date: 14 August 2020

To cite this article: Lee, S. P., \& Isa, M. (2020). Environmental, social and governance (ESG) practices and performance in Shariah firms: Agency or stakeholder theory? Asian Academy of Management Journal of Accounting and Finance, 16(1), 1-34. https://doi.org/10.21315/ aamjaf2020.16.1.1

To link to this article: https://doi.org/10.21315/aamjaf2020.16.1.1

(C) Asian Academy of Management and Penerbit Universiti Sains Malaysia, 2020. This work is licensed under the terms of the Creative Commons Attribution (CC BY) (http://creativecommons. org/licenses/by/4.0/). 


\section{INTRODUCTION}

This study provides preliminary evidence concerning the impact of ESG (environmental, social and governance) practices on performance among Shariahcompliant companies. It has been suggested in the literature that companies that embrace robust ESG practices are best positioned to achieve sustainable growth and profitability (Odell \& Ali, 2016). Although corporate sustainability initiatives may reduce near-term earnings, they are not expected to sacrifice longer-run value. Business sustainability is a concept of the commitment of businesses to maximise the economic benefits of shareholders while protecting the interests of all stakeholders in terms of the ESG dimensions. In this sense, managers need to be aware of the impact of business decisions on the environment, society at large, and firms' organisational structure. The Governance and Accountability Institute (2017) reveal that, in $2017,82 \%$ of S\&P 500 companies had engaged and adopted sustainability reporting, which represents a marked improvement from 53\% in 2012. The figures reveal the growing trend in firms to integrate ESG activities into their business practices in pursuing sustainable corporate development.

The early thinking of ESG activities is that it is an agency problem that leads to wealth deterioration. This is clearly portrayed by Friedman (1970) who argues that the corporate manager, as the agent, should conduct the business in accordance with the shareholders' desire for wealth maximisation. In other words, firms should not spend corporate resources on things such as environmental, social good governance activities as they will decrease shareholder value. Several studies argue that corporate social responsibility (CSR) activities are manifestations of managerial agency problems (Benabou \& Tirole, 2010; Masulis \& Reza, 2015). Brown, Helland and Smith (2006) and Kruger (2015) find that managers engaging in corporate philanthropy benefit themselves at the expense of shareholders. Similarly, agency costs are incurred when managers invest in social activities to promote their personal reputation (Barnea \& Rubin, 2010), and can lose focus on core managerial responsibilities (Jensen, 2002). Overall, based on the agency view, ESG practices are generally not in the interest of shareholders.

However, today there are many companies incorporating ESG in their business practices to reinforce their relationship with society and employees. The counterargument to Friedman's view is the stakeholder theory of Freeman (1994). Freeman suggests that managers of firms should be accountable to shareholders and all other stakeholders. The stakeholder theory is relevant to firms that promote efforts to help protect the environment, seek to improve social welfare and community relations, and often do adhere to value-maximising governance practices. Based on the stakeholder perspective, studies such as Edmans (2011), 
and Deng, Kang and Low (2013), state that good management firms with value maximisation can incorporate stakeholder value, not merely shareholder value. As such, good management firms are more likely to engage with ESG activities.

According to Ferrell, Liang and Renneboog (2016, p. 586), studies testing agency or stakeholder views on firms' involvement in ESG show mixed findings, thus leaving the issues raised in the almost century old Berle-Dodd debate largely unresolved. Cheng, Hong and Shue (2013) find that managers of large U.S. firms enjoy private benefits from investing in ESG at the expense of shareholder value, which is consistent with agency theory. In contrast, there are studies that find evidence consistent with the stakeholder views of ESG involvement, such as employees who are happy would work harder to increase productivity (Baron, 2008), reduce material and energy consumption (Qi et al., 2014), and build good relationships with regulators, employees, society and customers (Hou, 2019). However, prior literature (e.g. Lee \& Faff, 2009; Dhaliwal, Li, Tsang, \& Yang, 2011; Verheyden, Eccles, \& Feiner, 2016) appears to be inconclusive with respect to the relationship between ESG and financial performance. Therefore, whether and how ESG practices relate to financial performance is still a point of contention and debate amongst researchers and managers (Lu, Chau, Wang, \& Pan, 2014; Wang \& Sarkis, 2017).

Currently, Islamic finance has a strong financial and institutional network all over the world. Over the past decade, the market for Islamic finance industry has experienced tremendous growth. Thomson Reuters Islamic Banking and Finance Summit (2010) reports an average growth rate of $10 \%$ per year, with total assets of approximately USD2 trillion in 2015 and expected to reach USD3.3 trillion by 2020. There is now a Morgan Stanley Capital International (MSCI) World Islamic Index, which consists of 513 Shariah-compliant companies from 23 developed markets in December 2018. Despite the strong interest in Islamic financial research, studies of ESG practices on Shariah companies are very rare. At present, Erragragui and Revelli (2016) is the only study we find examining the performance of Islamic portfolios in relation to ESG scores. The results of their four-factor model indicate no adverse effects on returns due to the application of ESG screens on Shariah-compliant stocks during the 2007-2011 period. They also find a higher performance for the portfolios with good ESG records. Our study is different from Erragragui and Revelli (2016) in that they study ESG and portfolio returns, whereas we look at ESG and corporate performance.

With the current interest in Islamic financial research, as well as in firms ESG practices, it would be both interesting and beneficial to conduct ESG studies focusing on Shariah firms. What makes the study interesting is that these 
companies can be considered "ethical" companies in the sense that they are not involved in "sin" activities in addition to having a moderate interest-bearing debt level. One can expect that the impact of ESG activities on the performance of Shariah companies would be more pronounced because they are the most virtuous companies practicing ESG activities. In this study, we intend to fill this research gap in the literature on corporate finance and Shariah firms by combining the two screens and test the agency and stakeholder theories to examine the effects of ESG involvement on financial performance.

Our study contributes in the following manner. First, considering the tremendous growth of Islamic finance, academic studies on Shariah firms are still limited, particularly on ESG practices. This clearly indicates the importance of investigating the ESG decisions of these firms. Second, generally, prior studies have only focused on the impact of ESG on firm performance (e.g. Lee, Faff, \& Rekker, 2013; Halbritter \& Dorfleitner, 2015; Fatemi, Glaum, \& Kaiser, 2018 ) without testing any of the corporate finance theories. This study tests two competing theories, i.e., the agency and the stakeholder theory. Third, we use a large data set with global coverage. There has been a tremendous increase in the constituents of the MSCI World Islamic Index that integrates ESG practices. At present, more than $95 \%$ of the firms on the ASSET4 database disclose ESG information. Fourth, the results of our study present important evidence for two areas of interest: Islamic finance and corporate management theory. The evidence could be useful for policymakers in promoting ESG activities among Shariahcompliant firms.

\section{ESG AND SHARIAH SCREENING}

The ESG screening covers a range of issues related to company activities that include environmental concerns, social relations, and corporate governance to promote sustainable business practices (Thomson Reuters ESG Scores, 2017). The environmental (E) screen is mainly related to resource use, emissions, and innovation. This includes the company's approach and performance on recycling, waste management, greenhouse gas emissions, climate change and other types of environmental impact. The social (S) screen issues are associated with taking care of the workforce, human rights, community interests, and product responsibility. This includes the company's ability to generate trust and loyalty with its stakeholders, such as customers, society and governments. The governance $(\mathrm{G})$ screen concerns the interest and welfare of the management and shareholders, and corporate social responsibility. These include the company's commitment and effectiveness towards following best practice corporate governance principles; 
equal treatment of shareholders and the use of anti-takeover devices; and integration of the financial, social and environmental dimensions into its day-today decision-making processes.

The Shariah screening procedures administered by the MSCI Islamic Index Series Methodology (2017) consists of two levels: (1) business activity screen, and (2) financial screen. In the business activity screen, firms are excluded if they are directly involved in, or derive more than $5 \%$ of their revenue from such businesses as alcohol, tobacco, pork-related products, conventional financial services, weaponry, gambling, music, hotels, cinemas and adult entertainment. In the financial screen, a limit of $33.33 \%$ is applied to each of the following ratios: (1) total non-Shariah debt to total assets, (2) the sum of cash and interest-bearing securities over total assets, and (3) the sum of accounts receivables and cash over total assets.

As can be seen from the above explanation, there are similarities and differences between the ESG screen and the Shariah screen. The similarities are in the philosophy that both try to separate ethically and morally good companies that promote goodness to human life and preserve the environment from those that do not. Dusuki (2008) argues that Shariah screens are more specific because they are based on the moral and ethical principles from the Quran (the revealed word of God) and Sunnah (the sayings and practices of Prophet Muhammad), which are absolute from the Islamic point of view. Activities prohibited by Shariah may or may not be shared by the ESG screens and vice-versa. For example, environmental issues are not explicitly considered in Shariah screening, but these are important concerns of ESG screening (Charfeddine, Najah, \& Teulon, 2016). On the other hand, the application of financial ratio limits is applied to Shariah companies, but this is not relevant in ESG screening. Erragragui and Revelli (2016) present an extensive discussion on the interaction between the Shariah and ESG screens from the corporate and investors' perspectives.

\section{LITERATURE REVIEW AND HYPOTHESES DEVELOPMENT}

\section{Agency Theory}

Based on Jensen and Meckling's (1976) agency theory, it can be argued that the engagement of ESG presents an agency problem between managers and shareholders. According to this theory, ESG expenditure is not in the best interests of shareholders because it represents a direct outflow of funds that will reduce profits. Previous studies that find evidence consistent with agency theory include 
Brown et al. (2006), Barnea and Rubin (2010), Schuler and Cording (2006), Allouche and Laroche (2005), Kao, Yeh, Wang and Fung (2018), and Borghesi, Houston and Naranjo (2014).

There are at least three different ways that agency problems may manifest in relation to ESG activities. The first is when managers spend firm resources to gain private benefits. Managers may carry out ESG activities for their own personal interests (Brown et al., 2006), or overinvest to obtain private benefits by building their reputation as good citizens at a cost to shareholders (Barnea $\&$ Rubin, 2010). In this view, ESG engagement is a net waste of firm resources, and, hence, reduces firm performance. Secondly, ESG activities may result in firms having to sacrifice projects that would be more profitable for the firm (Schuler \& Cording, 2006). Allouche and Laroche (2005) state that corporate social accomplishments involve financial costs that are drawn from the capital and other resources, which will place the firm at a disadvantage compared to other firms that are less socially active. Thirdly, it is the managerial opportunism argument that suggests that managers use firm resources to engage in ESG activities to avoid negative attention and to offset or justify poor financial performance. This is often known as window dressing. ESG activities are carried out with the aim of getting good publicity as an effort to cover weak performance.

In this study, we extend the agency theory to cover the ESG engagement of Shariah firms and argue that the agency problems may be equally applicable to Shariah firms in the context of ESG decisions. Thus, based on the agency perspective, the first testable hypothesis is formulated as follows:

H1: Based on the agency theory, there is a negative relationship between ESG engagement and firm performance.

It has been suggested in the literature that firms with high liquidity and/or no financial constraints are prone to agency problems in relation to ESG activities. High liquidity may be shown in the form of high capital expenditure and free cash flows and these can be an indication of agency costs (Jensen, 1986; Masulis, Wang, \& Xie, 2009; Servaes \& Tamayo, 2014; Kruger, 2015; Ferrell et al., 2016). Cash is the most liquid asset as it gives managers the most freedom as to when and how to spend, and firms' capital expenditure decisions could be a channel of spending the cash for private benefit (Masulis et al., 2009). Hence, having higher liquidity than is appropriate may be detrimental to 
performance. In this respect, the liquidity variable, acting in conjunction with ESG, would have a negative relationship with financial performance. We therefore test the following hypothesis:

$\mathrm{H} 2$ : Liquidity variables acting in conjunction with ESG engagement would have a negative effect on firm performance.

On the contrary, Ferrell et al. (2016) argue that high financial constraints, as shown by high dividend and leverage proxies can help to mitigate managerial agency problems due to close shareholder and market monitoring. La Porta, Lopez-de-Silanes, Shleifer and Vishny (2000), and Morck and Yeung (2005) state that dividend and debt interest cash flows can help to prevent managers committing to unprofitable projects or activities that generate private benefits to insiders. High financial constraints can therefore serve to prevent the misuse of resources by the management. In this respect, the financial constraint variables acting in conjunction with ESG would have a positive relationship with financial performance. We therefore test the following hypothesis for the interaction of financial constraints with ESG activities:

H3: Financial constraint variables acting in conjunction with ESG engagement would have a positive effect on firm performance.

\section{Stakeholder Theory}

The stakeholder theory states that the better a firm manages relationships with all stakeholders, the more successful it will be over time. The stakeholders include individual or groups who benefit from or are harmed by firms' actions (Freeman, 1994). Freeman's theory suggests that a company's real success lies in satisfying all its stakeholders, not just shareholders. Based on the stakeholder theory, ESG activities are transferable or synergised into a firm's market performance. For example, satisfied and happy employees will be more motivated in their jobs; satisfied customers will foster loyalty, satisfied suppliers will provide discounts, and so forth, which, in turn, enhances a firm's reputation, and leads to better financial performance and sustainability. Jo and Harjoto (2012), and El Ghoul, Guedhami and Kim (2017) find that ESG engagement positively affects firm performance because ESG activities can resolve conflicts between managers and stakeholders. This implies that the policies of active ESG initiatives are instrumental in protecting the bottom line as well as increasing shareholder value. 
Since Shariah firms are those that have passed ethics and morality tests, we expect that Shariah firms would have a greater likelihood of good management practices to engage in ESG, which will result in the improved relationship between firms and their stakeholders that will benefit the firms in the short-run as well as in the long-run. Using the stakeholder theory as the premise, we propose the following hypothesis:

H4: Based on the stakeholder theory, there is a positive relationship between ESG engagement and firm performance.

\section{Financial Slack Hypothesis}

Since ESG expenditure is discretionary in nature, firms may be more willing to engage in ESG if they have abundant internal resources in the form of financial slack. Kraatz and Zajac (2001) define financial slack as a set of handy-to-use assets, such as cash and other liquid assets that can be easily deployed. Since the financial benefits generated from ESG engagement are uncertain, when ample financial slack exists, firms are able to engage in more ESG activities and send a credible signal to stakeholders. According to Campbell (2007), firms with abundant resources are more capable of absorbing additional costs and more willing to undertake environmental and social activities in their business strategies. Qi et al. (2014) and Tan, Habibullah, Tan and Choon (2017) find that financial slack acts as a moderating effect on ESG practices and firm performance.

From the perspective of Islamic finance, the availability of financial slack plays an important role in allowing firms to engage in ESG activities. It is reasonable to assume that Shariah firms with more financial slack are more inclined to engage in ESG activities than firms with the least financial slack. Thus, based on the financial slack arguments, the following hypothesis is formulated:

H5: Financial slack acting in conjunction with ESG engagement would have a positive effect on firm performance.

\section{DATA AND METHODOLOGY}

\section{Data}

Our sample consists of Shariah stocks included in the MSCI World Islamic Index for the period of 2010-2017. The information pertaining to firms' involvement in ESG activities is obtained from the Thomson Reuters ASSET4 database. 
Our sample consists of a balanced panel dataset of 461 firms over the 8-year period, giving a total of 3688 firm-year observations. We choose 2010 as the starting year due to information availability on the constituents of the MSCI World Islamic Index.

Table 1 presents the sample breakdown by industry and country. The final sample covers 20 industry groups in 20 countries. We use the industry classification provided by the ASSET4 database to take into account the firm's industry characteristics. The ASSET4 database provides information on the country of domicile and the industry code (Thomson Reuters Business Classification). The ones with the greatest numbers of observations are oil and gas $(11.93 \%)$, machinery $(9.98 \%)$, personal goods $(6.94 \%)$, and food products (6.72\%). The sample primarily includes firms from developed markets, mainly the United States (30.15\%), Japan (23.64\%), and the United Kingdom (8.24\%).

Table 1

Sample breakdown by industry and country

\begin{tabular}{lcclrc}
\hline Industry & No. obs. & $\%$ & Country & No. obs. & \multicolumn{1}{c}{$\%$} \\
\hline Automobiles and parts & 26 & 5.64 & United States & 139 & 30.15 \\
Chemicals & 29 & 6.29 & Japan & 109 & 23.64 \\
Construction and material & 28 & 6.07 & United Kingdom & 38 & 8.24 \\
Electronic equipment & 15 & 3.25 & Canada & 27 & 5.86 \\
Food products & 31 & 6.72 & France & 24 & 5.21 \\
Healthcare & 18 & 3.90 & Australia & 23 & 4.99 \\
Machinery & 46 & 9.98 & Germany & 22 & 4.77 \\
Media & 6 & 1.30 & Switzerland & 13 & 2.82 \\
Metals & 27 & 5.86 & Hong Kong & 10 & 2.17 \\
Oil and gas & 55 & 11.93 & Sweden & 9 & 1.95 \\
Personal goods & 32 & 6.94 & Netherlands & 9 & 1.95 \\
Pharmaceutical products & 29 & 6.29 & Singapore & 8 & 1.74 \\
Professional services & 12 & 2.60 & Finland & 6 & 1.30 \\
Real estate & 16 & 3.47 & Norway & 5 & 1.08 \\
Specialty retailers & 19 & 4.12 & Spain & 4 & 0.87 \\
Software and computer services & 18 & 3.90 & Italy & 4 & 0.87 \\
Technology & 13 & 2.82 & Belgium & 4 & 0.87 \\
Telecommunications & 6 & 1.30 & Denmark & 3 & 0.65 \\
Textiles & 11 & 2.39 & Austria & 2 & 0.43 \\
Transportation & 24 & 5.21 & New Zealand & 2 & 0.43 \\
\hline
\end{tabular}

Notes: This table presents the industry and country distribution for 461 firms in our study between 2010 and 2017. 


\section{Measurement of Variables}

\section{Dependent variables}

This study uses two different proxies for firm performance measures. The two measures are return on assets $(R O A)$ and economic sustainability performance (Econ). Following Qi et al. (2014) and Li et al. (2017), we only employed ROA for financial performance because this is the most commonly used measure in the literature. $R O A$ is computed as net income over average total assets. We also employ a second measure of performance obtained from the Thomson Reuters ASSET4 database, called "Econ". This measures a firm's ability to efficiently use resources to generate a high return on investment and sustainable growth (Jitmaneeroj, 2016). Ng and Rezaee (2015) state that Econ has a clearly defined objective function of creating shareholder value. Such information is certified by management, audited by independent auditors, and often reviewed by regulators, and thus, it is less susceptible to information asymmetry. According to DataStream, Econ measures a company's capacity to generate sustainable growth and a high return on investment through the efficient use of all its resources, and is a reflection of a company's overall financial health and its ability to generate long-term shareholder value through its use of best management practices.

\section{ESG scores}

The ESG scores are also extracted from the ASSET4 database. ESG scores cover the following categories: Environment (Envir), which relates to resource use, emissions and innovation; Social $(S o c)$, which concerns relations with the workforce, human rights, community, and product responsibility; Governance (Gov), which focuses on issues related to management, shareholders and CSR strategy. The Thomson Reuters ASSET4 scores run from 0 to 100 . The database provides the aggregate ESG score as well as individual scores for each element of Envir, Soc and Gov. For details of the calculation please refer to Thomson Reuters ESG scores (2017).

\section{Liquidity and financial constraints variables}

Based on previous literature (e.g., Ferrell et al., 2016), the liquidity and financial constraints may be considered as agency proxies because they are likely to influence agency spending. In this study, we use the following variables to represent agency proxies: (1) free cash flow $(F C F)$ measured by earnings before interest and tax expenses (EBIT) after the change in net assets, scaled by total assets; (2) capital expenditure (CapEx), scaled by total assets; (3) dividend pay- 
out (DivSale), scaled by sales; and (4) level of leverage (Leverage), measured as total debt over total equity. The first two variables are liquidity proxies, while the last two are financial constraint proxies.

\section{Financial slack variables}

Financial slack theorists argue that the availability of financial slack provides the opportunity for firms to invest in ESG activities. Mattingly and Olsen (2018) state that a firm's financial slack exists in various degrees. Consistent with prior studies (i.e., Ferrell et al., 2016; Tan et al., 2017; Zhang et al., 2018; Mattingly \& Olsen, 2018), we use two financial ratios to represent financial slack: (1) Cash ratio, computed as the ratio of cash and equivalents to total assets; and (2) current ratio (CurRatio) measured as current assets over current liabilities.

\section{Control variables}

In addition to the ESG, agency and financial slack variables, we include a number of measures commonly used in the analysis of firm performance as control variables. These measures include firm size (Size), calculated as the natural logarithm of total assets; research and development intensity ( $R \& D$ intensity), computed as research and development expenditure scaled by total assets; the operating performance (Assets turnover) is measured as assets turnover rate, which is calculated as operating revenue scaled by total assets; and the ratio of market to book value of equity $(M T B)$, which is computed as the market value of assets to the book value of assets.

\section{Model Specification}

\section{The empirical model for the agency versus stakeholder theory (H1 and H4)}

To test H1 and H4, we follow Ferreira and Laux (2007) by using a lead-lag panel regression to test the relationship between firm performance and the aggregate ESG as well as the individual dimensions of ESG, namely, Envir, Soc and Gov:

$$
\begin{aligned}
F P_{i, t}= & \alpha+\varphi_{1} \text { ESG }_{i, t-1}+\beta_{1} \text { Size }_{i, t-1}+\beta_{2} \text { AssetsTurnover }_{i, t-1} \\
& +\beta_{3} \text { MTB }_{i, t-1}+\beta_{4} R \& D_{i, t-1}+\gamma_{i}+\delta_{t}+\lambda_{i}+\varepsilon_{i, t} \\
F_{i, t}= & \alpha+\varphi_{1} \text { Envir }_{i, t-1}+\varphi_{2} \text { Soc }_{i, t-1}+\varphi_{3} \text { Gov }_{i, t-1}+\beta_{1} \text { Size }_{i, t-1} \\
& +\beta_{2} \text { AssetsTurnover }_{i, t-1}+\beta_{3} \text { MTB }_{i, t-1}+\beta_{4} \text { R\&D }_{i, t-1} \\
& +\gamma_{i}+\delta_{t}+\lambda_{i}+\varepsilon_{i, t}
\end{aligned}
$$

where the $F P$ denotes firm performance measured by $R O A$ and Econ. ESG represents aggregate ESG score. In Equation (2), we repeat the regression by 
replacing the ESG with individual elements of Envir, Soc and Gov to estimate the differential effect of these elements on firm performance. The subscript $i$ denotes individual firm and $t$ is the year. $\gamma_{i}, \delta_{t}$ and $\lambda_{i}$ denote country, industry and year fixed effects, respectively, while $\varepsilon_{i, t}$ is the random error term.

\section{The empirical model for testing liquidity and financial constraints ( $\mathrm{H} 2$ and $\mathrm{H} 3$ )}

$\mathrm{H} 2$ and $\mathrm{H} 3$ specifically focus on testing if the ESG activities are motivated by liquidity or financial constraints. These tests use four agency variables, which are the FCF and CapEx to represent liquidity and Leverage, and DivSale to represent financial constraints. These variables are included in the following regressions:

$$
\begin{aligned}
& F P_{i, t}=\alpha+\varphi_{1} E S G_{i, t-1}+\beta_{1} \text { Agency }_{i, t-1}+\beta_{2} E S G_{i, t-1} \\
& +\beta_{3} \text { Size }_{i, t-1}+\beta_{4} \text { AssetsTurnover }_{i, t-1}+\beta_{5} \text { MTB }_{i, t-1} \\
& +\beta_{6} R \& D_{i, t-1}+\gamma_{i}+\delta_{t}+\lambda_{i}+\varepsilon_{i, t} \\
& F P_{i, t}=\alpha+\varphi_{1} \text { Envir }_{i, t-1}+\varphi_{2} \text { Soc }_{i, t-1}+\varphi_{3} \text { Gov }_{i, t-1}+\beta_{1} \text { Envir }_{i, t-1} \\
& * \text { Agency }_{i, t-1}+\beta_{2} \text { Soc }_{i, t-1} * \text { Agency }_{i, t-1}+\beta_{3} \text { Gov }_{i, t-1} \\
& \text { * } \text { Agency }_{i, t-1}+\beta_{4} \text { Size }_{i, t-1}+\beta_{5} \text { AssetsTurnover }_{i, t-1} \\
& +\beta_{6} M T B_{i, t-1}+\beta_{7} R \& D_{i, t-1}+\gamma_{i}+\delta_{t}+\lambda_{i}+\varepsilon_{i, t}
\end{aligned}
$$

Following the arguments of Ferrell et al. (2016), we predict that the coefficients for the first two interaction variables $\left(E S G^{*} F C F\right.$ and $\left.E S G^{*} C a p E x\right)$ will be negative, and that the coefficients for the last two interaction variables (ESG*leverage and ESG*DivSale) will be positive.

However, Ferrell et al. (2016) state that firms with higher $F C F$ and CapEx do not necessarily reflect higher agency costs as long as there are sufficient investment opportunities and growth. To address this concern, we rank our data based on the agency variables and transform them into dummy variables, in which the top one-third are given the value of 1 and others 0 . Based on our earlier argument, only firms with high values of the variables are more likely to engage in ESG activities for private benefit and this should be captured by the interaction variables.

\section{The empirical model for financial slack (H5)}

To test the financial slack hypothesis (H5), in which financial slack acts as the moderating effect on the relationship between ESG and firms performance, we compute the interaction between ESG and financial slack based on the following models: 


$$
\begin{aligned}
F_{i, t}= & \alpha+\varphi_{1} \text { ESG }_{i, t-1}+\beta_{1} \text { FinancialSlack }_{i, t-1}+\beta_{2} \text { ESG }_{i, t-1} \\
& * \text { Financialslack }_{i, t-1}+\beta_{3} \text { Size }_{i, t-1}+\beta_{4} \text { AssetsTurnover }_{i, t-1} \\
& +\beta_{5} \text { MTB }_{i, t-1}+\beta_{6} R \& D_{i, t-1}+\gamma_{i}+\delta_{t}+\lambda_{i}+\varepsilon_{i, t} \\
\text { FP }_{i, t}= & \alpha+\varphi_{1} \text { Envir }_{i, t-1}+\varphi_{2} \text { Soc }_{i, t-1}+\varphi_{1} \text { Gov }_{i, t-1}+\beta_{2} \text { Envir }_{i, t-1} \\
& * \text { FinancialSlack }_{i, t-1}+\beta_{2} \text { Soc }_{i, t-1} * \text { FinancialSlack }_{i, t-1} \\
& +\beta_{3} \text { Gov }_{i, t-1} * \text { FinancialSlack }_{i, t-1}+\beta_{2} \text { Size }_{i, t-1} \\
& +\beta_{3} \text { AssetsTurnover }_{i, t-1}+\beta_{4} \text { MTB }_{i, t-1}+\beta_{5} \text { R\&D } \\
& +\gamma_{i, t-1} \\
& +\gamma_{i}+\delta_{t}+\lambda_{i}+\varepsilon_{i, t}
\end{aligned}
$$

We use two alternative financial slack variables: (1) Cash ratio and (2) CurRatio. The financial slack hypothesis predicts a positive coefficient for the interaction terms. We rank Cash ratio and CurRatio data, and transform them into dummy variables, in which the top one-third are given the value of 1 and others 0 .

\section{RESULTS AND DISCUSSION}

\section{Descriptive Statistics and Correlation}

Table 2 presents the descriptive statistics of the variables used in the regression model. The mean (standard deviation) value of $R O A$ is $6.65 \%(6.17 \%)$. Regarding the economic (Econ) and the ESG score, the mean values are 72.43 and 62.70, respectively. Within the individual dimensions, environmental has the highest mean value of 74.51 , followed by social with 72.55 , while governance has the lowest mean value of 60.07 .

In terms of the mean values for the agency variables, the free cash flow to total assets range varies between -0.21 and 0.40 , with a mean value of 0.095 . The average ratio of capital expenditure to total assets is 5.06. The average leverage, i.e., total debt to equity ratio is $18.35 \%$ and varies between $0.01 \%$ and $32.20 \%$, and the standard deviation is $8.80 \%$, which is quite low, thereby showing a relatively low variation in the values. The mean of dividend pay-out to sales is $1.88 \%$. The cash holding to total assets and current ratio that measures the financial slack show a mean value of 0.08 and $1.83 \%$, respectively.

The statistics for the control variable, firm size (total assets), is USD28.612 billion, and the median value is USD10.919 billion. The market-to-book value, which measures a firm's growth opportunities, shows a mean value of 2.46. This indicates that the market as a whole has a generally good perception about the firm's future prospects. The average asset turnover and R\&D expenditure to total assets is $0.88 \%$ and 0.022 , respectively. 
Table 2

Descriptive statistics of key variables

\begin{tabular}{lrrrrr}
\hline & Mean & Median & \multicolumn{1}{c}{ Max } & Min & Std. dev. \\
\hline ROA & 6.650 & 5.940 & 37.930 & -30.680 & 6.169 \\
Econ & 72.432 & 81.280 & 98.590 & 2.420 & 24.104 \\
ESG & 62.695 & 65.080 & 97.520 & 8.020 & 16.282 \\
Environmental score & 74.508 & 88.340 & 95.500 & 8.480 & 26.405 \\
Social governance & 72.550 & 83.580 & 97.530 & 4.710 & 25.642 \\
Governance score & 60.068 & 72.760 & 98.220 & 1.180 & 32.196 \\
Free cash flows (scaled by total assets) & 0.095 & 0.089 & 0.399 & -0.209 & 0.055 \\
Capital expenditure (scaled by total assets) & 5.056 & 4.230 & 30.760 & 0.010 & 3.557 \\
(percent) & & & & & \\
Leverage ratio (percent) & 18.346 & 19.950 & 32.220 & 0.010 & 8.801 \\
Dividend payout (dividend to sales) & 1.883 & 0.498 & 18.480 & 0.000 & 3.211 \\
(percent) & & & & & \\
Cash holding (scaled by total assets) & 0.084 & 0.066 & 0.397 & 0.000 & 0.070 \\
Current ratio (percent) & 1.832 & 1.530 & 13.210 & 0.220 & 1.086 \\
Firm size (total assets) (billions of USD) & 28.612 & 10.919 & 533.712 & 0.161 & 53.154 \\
Market-to-book value & 2.456 & 1.850 & 16.710 & 0.180 & 1.968 \\
Assets turnover & 0.875 & 0.790 & 5.170 & 0.010 & 0.594 \\
Research and development & 0.022 & 0.005 & 0.449 & 0.000 & 0.036 \\
(scaled by total assets) & & & & & \\
\hline
\end{tabular}

Table 3 reports the Pearson pairwise correlation matrix of the dependent and independent variables used in our regression analysis. All of the correlation coefficients are below 0.80 . A correlation coefficient of more than 0.80 indicates a serious multicollinearity problem (Brooks, 2014). The results in Table 3 indicate that multicollinearity is not a problem, as the highest correlation coefficient among the independent variables is 0.78 between the social and the overall ESG score. Hence, multivariate analysis can be applied to examine the relationships between the dependent and independent variables. The correlation coefficients of overall ESG score with the $R O A$ is positive, which provides preliminary support for the stated hypotheses. 
ESG Practices and Performance in Shariah Firms

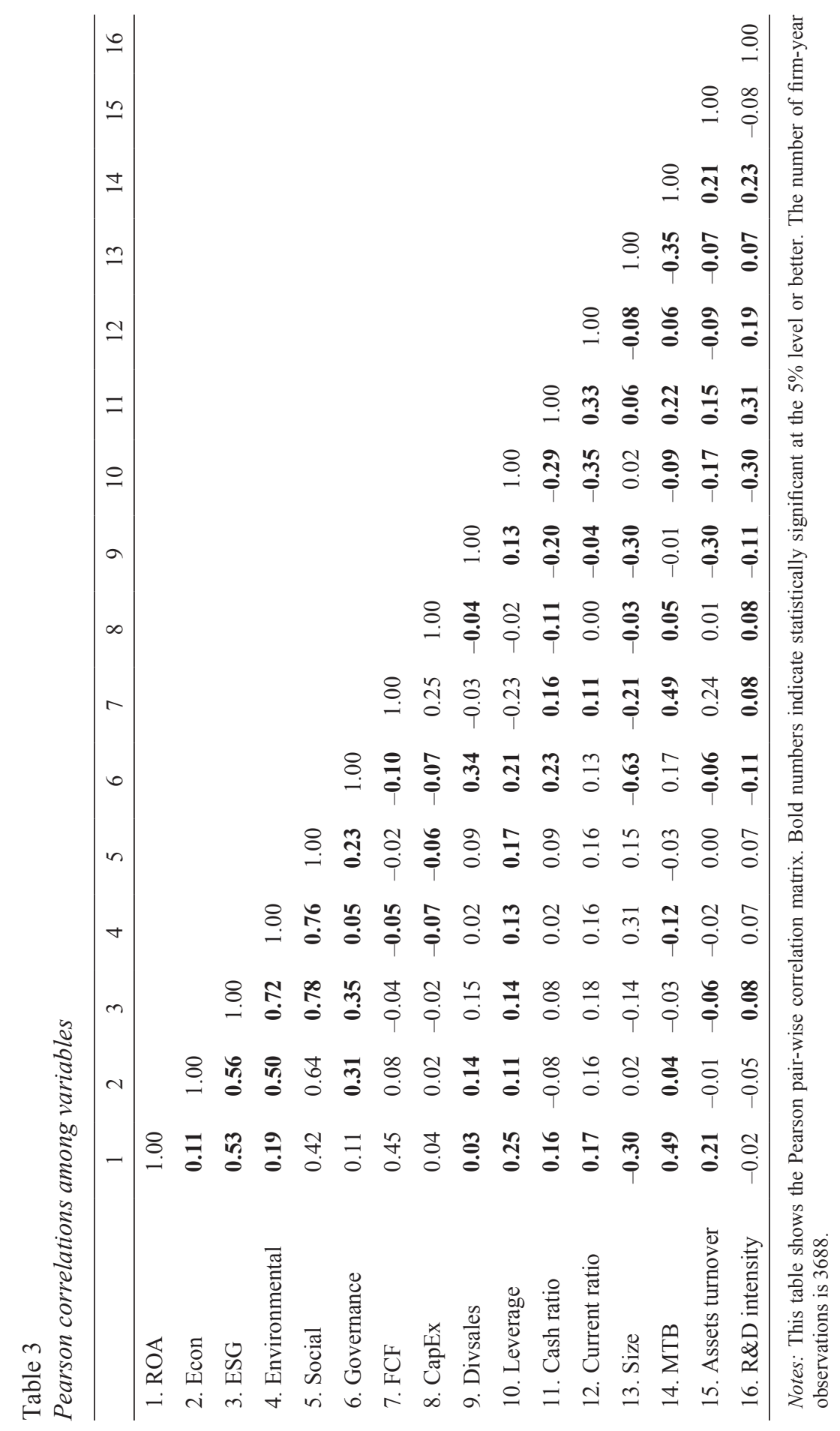




\section{Regression Results}

\section{Agency versus Stakeholder theory (H1 and H4)}

We first report the result between ESG and firm performance, without taking into account the agency and financial slack variables. Table 4 reports the regression results from estimating Equations 1 and 2, using the $R O A$ and Econ as the dependent variables. All regressions show significant $F$-statistics and the $R$-squared are reasonably high. The first two columns report the direct effects of the independent variable of aggregate ESG and the control variables (Size, Assets turnover, $M T B$ and $R \& D$ intensity). All the independent variables are lagged. As shown in Column 1, using $R O A$ as the dependent variable, the estimated coefficient associated with aggregate ESG is positive and significant at the $1 \%$ level. When using Econ as the dependent variable, Column 2 shows similar results. This means that ESG engagement improves firm performance. Regarding our control variables, the signs of the coefficients are largely consistent with the findings of the previous studies. First, the coefficient of firm Size and $R \& D$ intensity is negatively related to $R O A$, which is consistent with Li, Gong, Zhang and Koh (2018). Second, Assets turnover and MTB show statistically significant positive associations with firm performance.

The ESG variable refers to the aggregate score of the three individual dimensions of environmental, social and governance. Duuren, Plantinga and Scholtens (2016) find that investors may attach different weights to these factors. Therefore, we further investigate the relationship between individual ESG dimensions and firm performance. The results in Columns 3 and 4 show that all the individual ESG dimensions have positive effects on ROA and Econ. This suggests that each of the ESG dimension activities adds value to the firms. Our results are consistent with Kao et al. (2018) and Li et al. (2018).

Our results in Table 4 strongly indicate that the ESG aggregate score, as well as all the individual element scores, are positively related with both performance measures. This evidence is strongly in support of H4. This means our results are consistent with the stakeholder theory and reject the agency theory. Our results of the positive relationship are consistent with previous studies, such as Jo and Harjoto (2012), Qi et al. (2014), El Ghoul et al. (2017), and Hou (2019), but not consistent with studies that found a negative relationship, such as Lee and Faff (2009), Barnea and Rubin (2010), and Nollet, Filis and Mitrokostas (2016). 
Table 4

The impact of ESG and individual dimensions of environmental, social and governance on firm performance

\begin{tabular}{|c|c|c|c|c|}
\hline & $\begin{array}{c}(1) \\
\text { ROA }\end{array}$ & $\begin{array}{c}(2) \\
\text { Econ }\end{array}$ & $\begin{array}{c}(3) \\
\text { ROA }\end{array}$ & $\begin{array}{c}(4) \\
\text { Econ }\end{array}$ \\
\hline ESG & $\begin{array}{c}0.021 * * * \\
(3.507)\end{array}$ & $\begin{array}{l}0.731 * * * \\
(33.099)\end{array}$ & & \\
\hline Environmental & & & $\begin{array}{c}0.017 * * * \\
(2.984)\end{array}$ & $\begin{array}{l}0.012 * \\
(1.652)\end{array}$ \\
\hline Social & & & $\begin{array}{c}0.026^{* * *} \\
(4.374)\end{array}$ & $\begin{array}{c}0.510 * * * \\
(24.175)\end{array}$ \\
\hline Governance & & & $\begin{array}{c}0.007^{* * *} \\
(2.483)\end{array}$ & $\begin{array}{c}0.113 * * * \\
(11.050)\end{array}$ \\
\hline Size & $\begin{array}{c}-0.548 * * * \\
(-6.410)\end{array}$ & $\begin{array}{c}-2.828 * * * \\
(-8.692)\end{array}$ & $\begin{array}{c}-0.604 * * * \\
(-7.020)\end{array}$ & $\begin{array}{c}-1.861 * * * \\
(-6.285)\end{array}$ \\
\hline Assets turnover & $\begin{array}{l}0.990 * * * \\
(6.134)\end{array}$ & $\begin{array}{l}1.615 * * * \\
(2.566)\end{array}$ & $\begin{array}{l}1.025 * * * \\
(6.151)\end{array}$ & $\begin{array}{l}1.366 * * \\
(2.371)\end{array}$ \\
\hline МТВ & $\begin{array}{l}1.429 * * * \\
(29.626)\end{array}$ & $\begin{array}{c}1.091 * * * \\
(5.993)\end{array}$ & $\begin{array}{l}1.365 * * * \\
(27.419)\end{array}$ & $\begin{array}{l}0.503 * * \\
(2.904)\end{array}$ \\
\hline R\&D intensity & $\begin{array}{c}-0.312 * * * \\
(-9.521)\end{array}$ & $\begin{array}{c}-0.466^{* * *} \\
(-3.698)\end{array}$ & $\begin{array}{c}-0.301 * * * \\
(-9.042)\end{array}$ & $\begin{array}{c}-0.227^{* *} \\
(-2.001)\end{array}$ \\
\hline Intercept & $\begin{array}{c}10.469 * * * \\
(7.561)\end{array}$ & $\begin{array}{c}18.863 * * * \\
(3.645)\end{array}$ & $\begin{array}{c}11.696^{* * *} \\
(8.508)\end{array}$ & $\begin{array}{c}6.676 \\
(1.394)\end{array}$ \\
\hline $\begin{array}{l}\text { Country, industry and } \\
\text { year effects }\end{array}$ & Yes & Yes & Yes & Yes \\
\hline$F$-statistic & 65.750 & 80.300 & 62.840 & 112.630 \\
\hline$R$-squared & 0.335 & 0.372 & 0.333 & 0.480 \\
\hline
\end{tabular}

\section{Liquidity and financial constraint ( $\mathrm{H} 2$ and $\mathrm{H} 3$ )}

In this section, we test whether traditional corporate finance proxies for agency problems, such as liquidity and financial constraint, account for the ESG activities in the Shariah firms. $\mathrm{H} 2$ and $\mathrm{H} 3$ test these two views. For liquidity, we use two proxies; these are the FCF and CapExp, while for financial constraint, we use Leverage and Dividend pay-out as proxies. The agency view predicts that the liquidity variables have a negative effect on performance while the financial constraint variables have a positive relationship.

Table 5 reports the regression results. The $F$-statistics for all the regressions are significant and the $R$-squared are reasonably high, ranging from 0.35 to 0.42 . The relationship between aggregate ESG and performance 
remains positive. In Panel $\mathrm{A}$, the coefficients of the interaction variables of the liquidity variables (ESG*FCF and $\left.E S G^{*} C a p E x\right)$ are all positive and significant (see, Columns 1 and 2), while the interaction coefficients on financial constraint variables (ESG*leverage and ESG*DivSale) are largely insignificant (see Columns 3 and 4). These results are robust to the different performance proxies used, as shown in Panel B, where we substitute the dependent variable with Econ. The results are qualitatively similar. $\mathrm{H} 2$ and $\mathrm{H} 3$ are therefore not supported by our analysis. Instead, our results are the opposite of the predictions of the agency theory.

As another form of robustness test, we rerun the regressions replacing the aggregate ESG with the individual ESG components of environmental (Envir), social $(S o c)$, and governance (Gov). The results are presented in Table 6. Our focus is on the interaction variables. For both dependent variables, ROA and Econ, the results are very similar to the previous table. The coefficients for the first two agency proxies and their interaction variables are mostly positive, and for the last two variables and their interaction variables they are insignificant. All these findings therefore do not support the agency view that says ESG activities are detrimental to performance. The results shown in Table 6 corroborate with the earlier results that there is no reason to believe that the decision to engage in ESG is induced by agency motives. This reinforces our earlier findings supporting ESG activities to enhance the Shariah firm value. Our finding is consistent with Ferrell et al. (2016) in that they conclude that ESG activities are not induced by agency motives, but, instead, can improve firm performance. Regarding the control variables, the results in Tables 5 and 6 are qualitative, similar to those in Table 4.

\section{Financial slack (H5)}

Seifert, Morris and Bartkus (2004) argue that financial slack provides firms with a convenient way to be involved in ESG activities. It is also possible that good performance on ESG is more likely to arise when firms are financially in a strong position, and, thus, have ample resources to engage in ESG related activities. Our $\mathrm{H} 5$ is to test the moderating influence of financial slack on firm performance. We include two financial slack proxies, cash ratio and current ratio, into the regression equations. Table 7 reports the regression results. Again, the relationship between aggregate ESG and firm performance remains positive. However, the variables of interest are the interaction variables in Columns 1 to 4, which are the $E S G^{*}$ Cash ratio and $E S G^{*}$ CurRatio. It is observed that the coefficients of the interaction variable (ESG*Cash ratio and ESG*CurRatio) are not significant, except in Column 4. In general, the role of financial slack is quite insignificant. 
ESG Practices and Performance in Shariah Firms

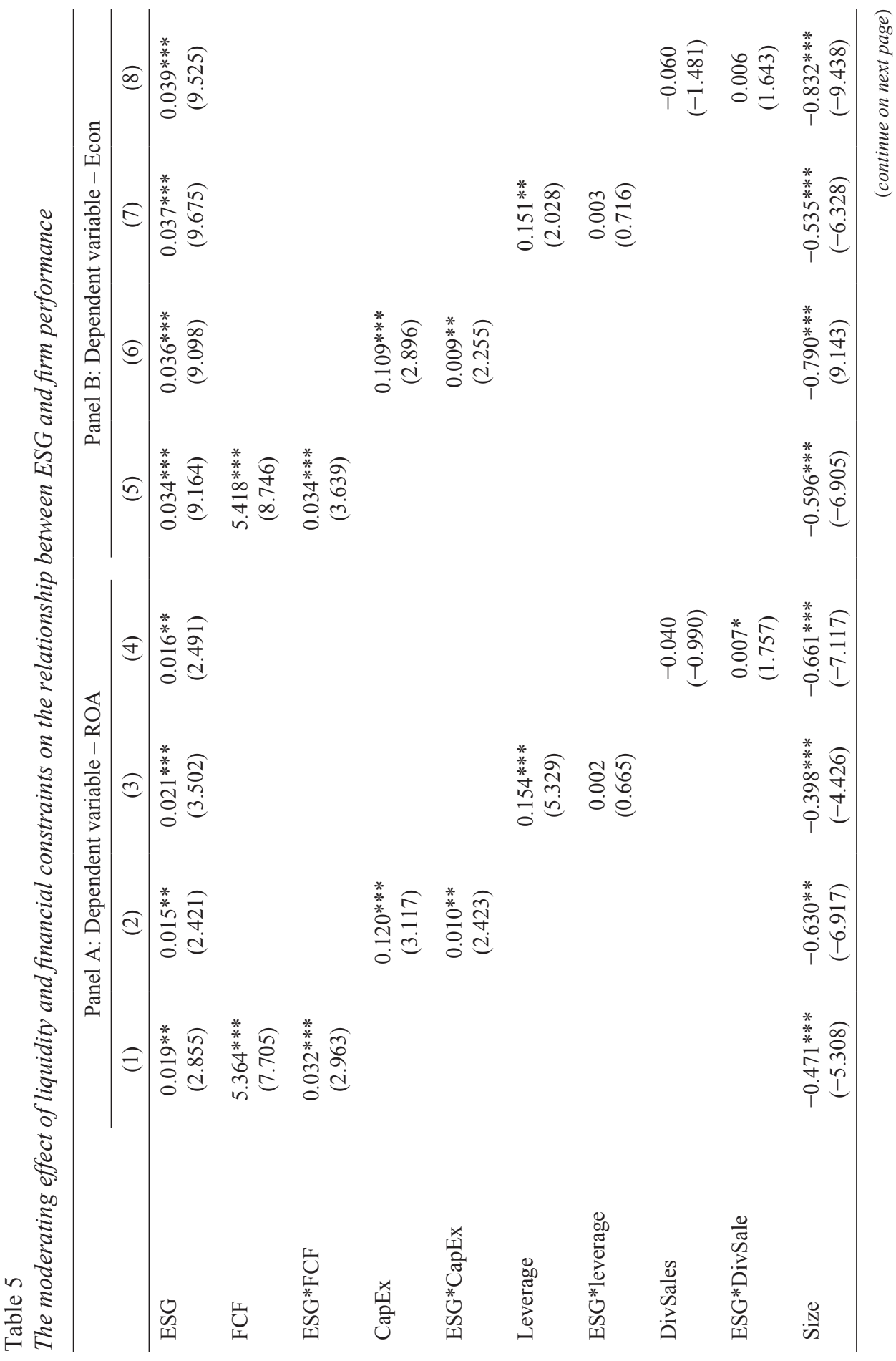




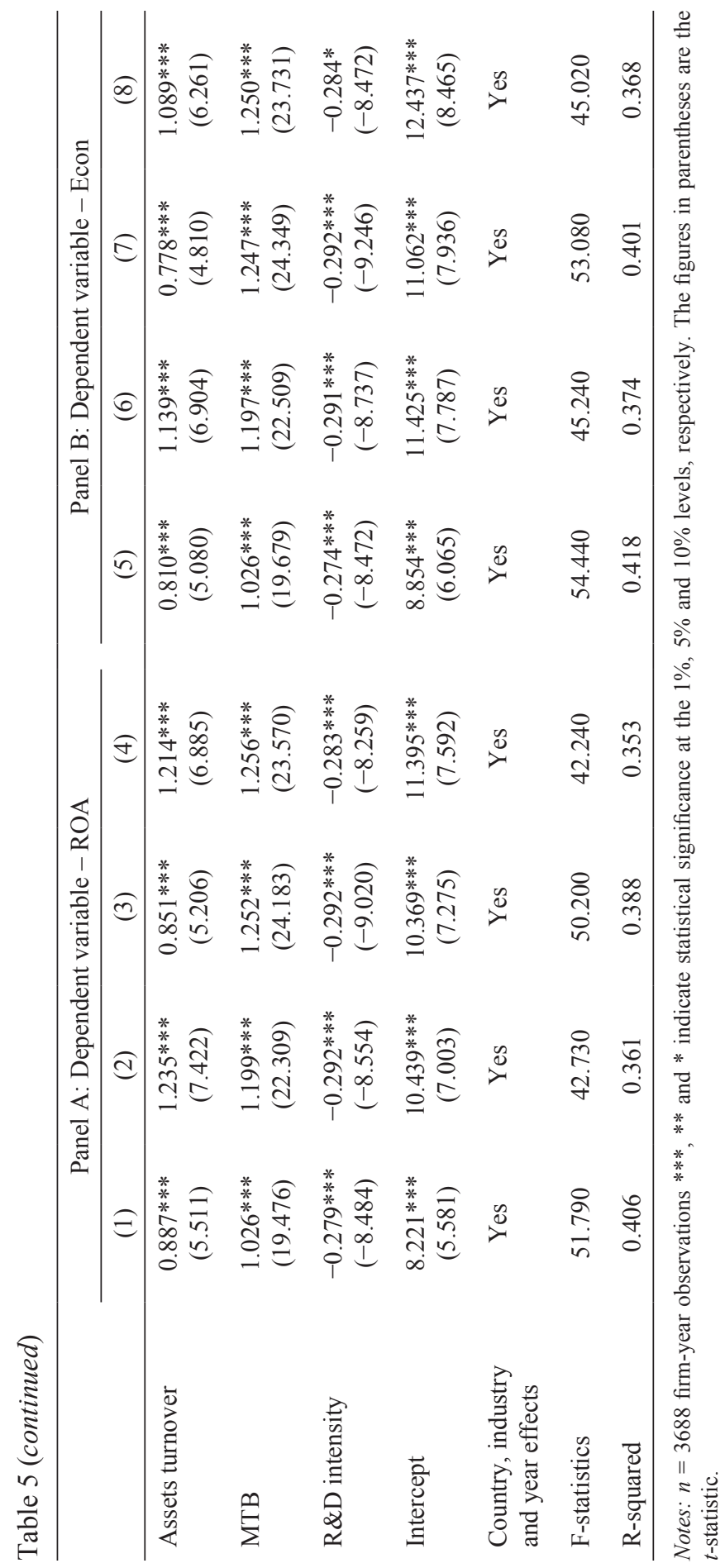




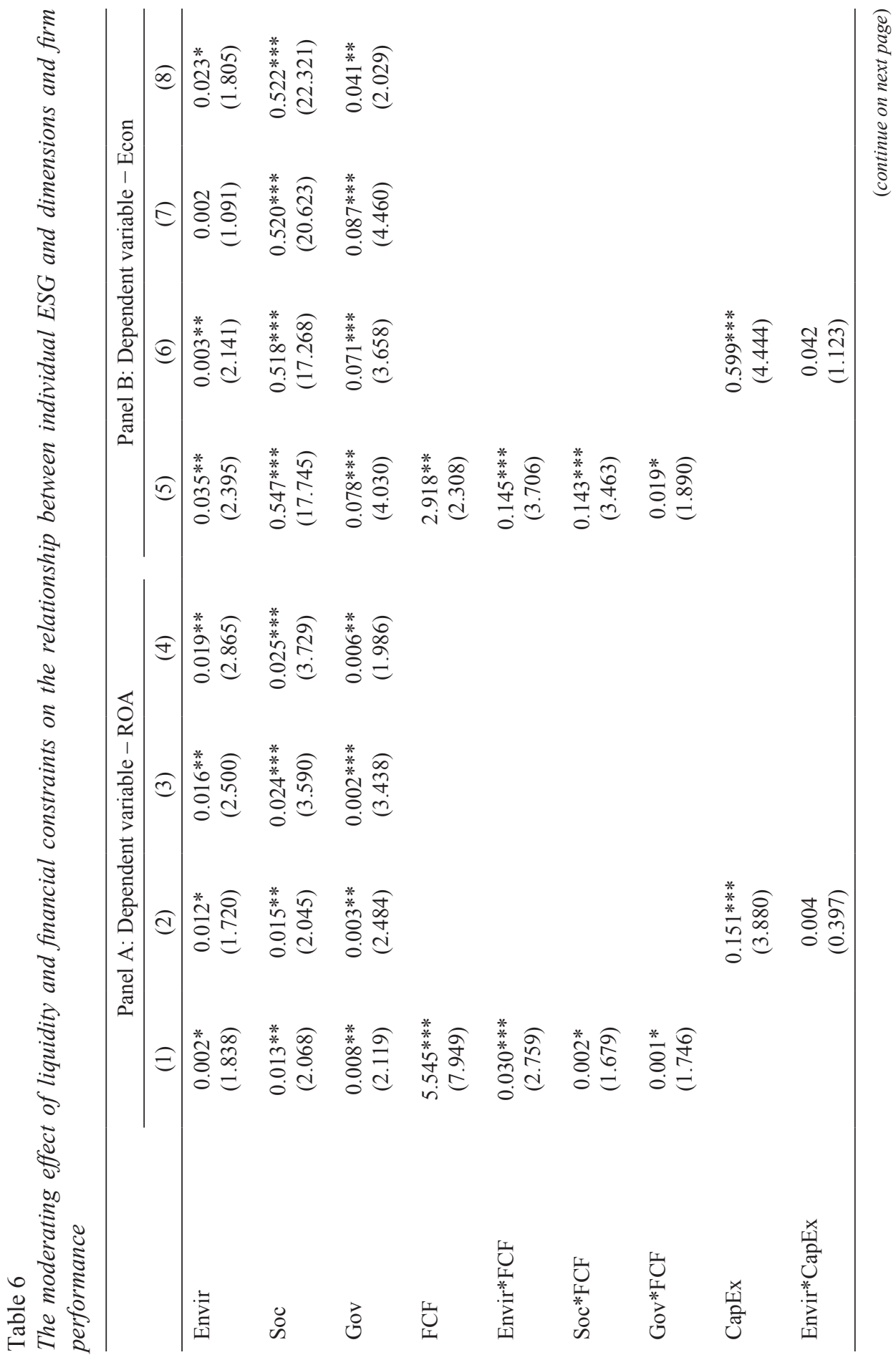


Lee Siew Peng and Mansor Isa

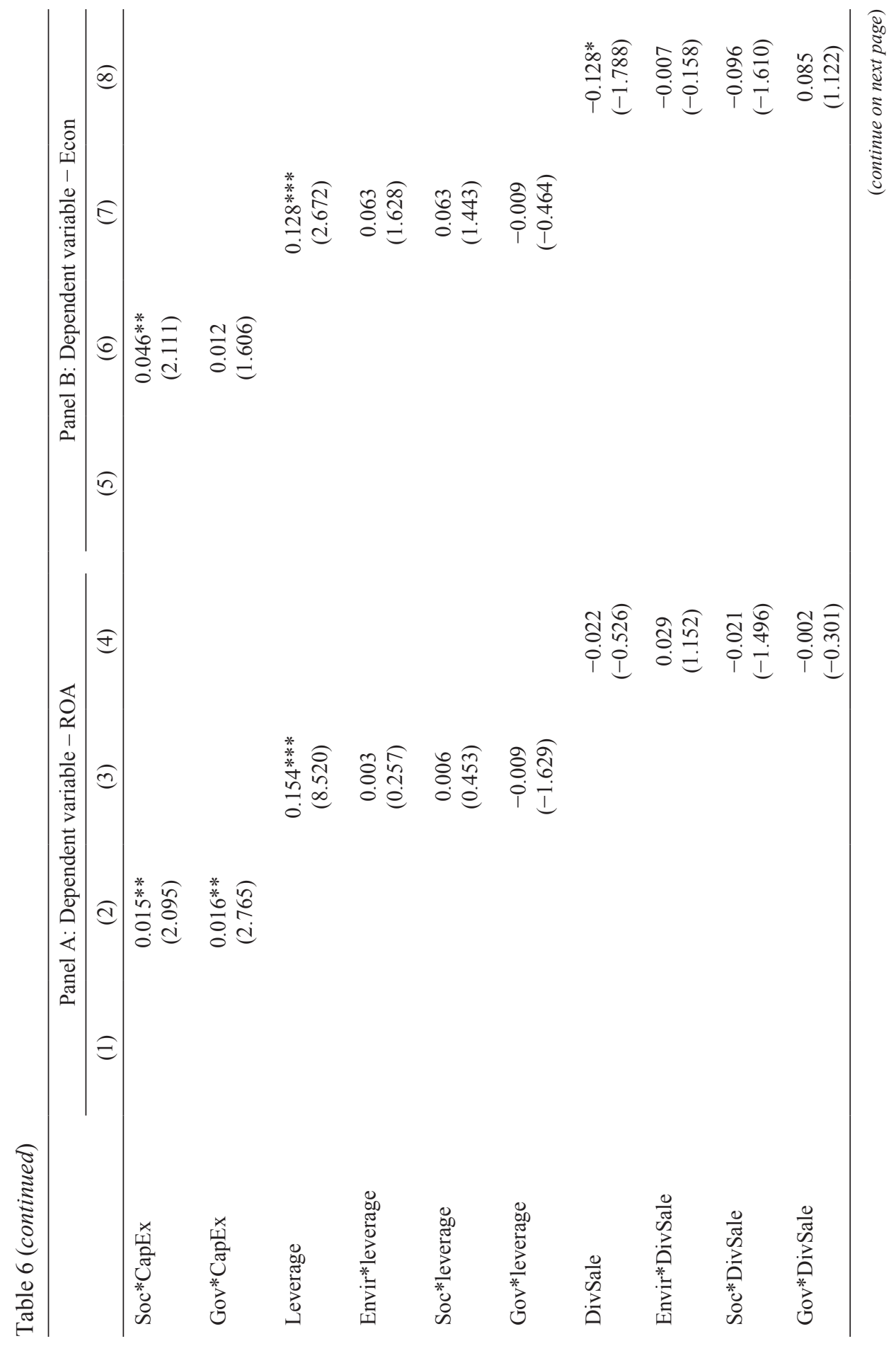




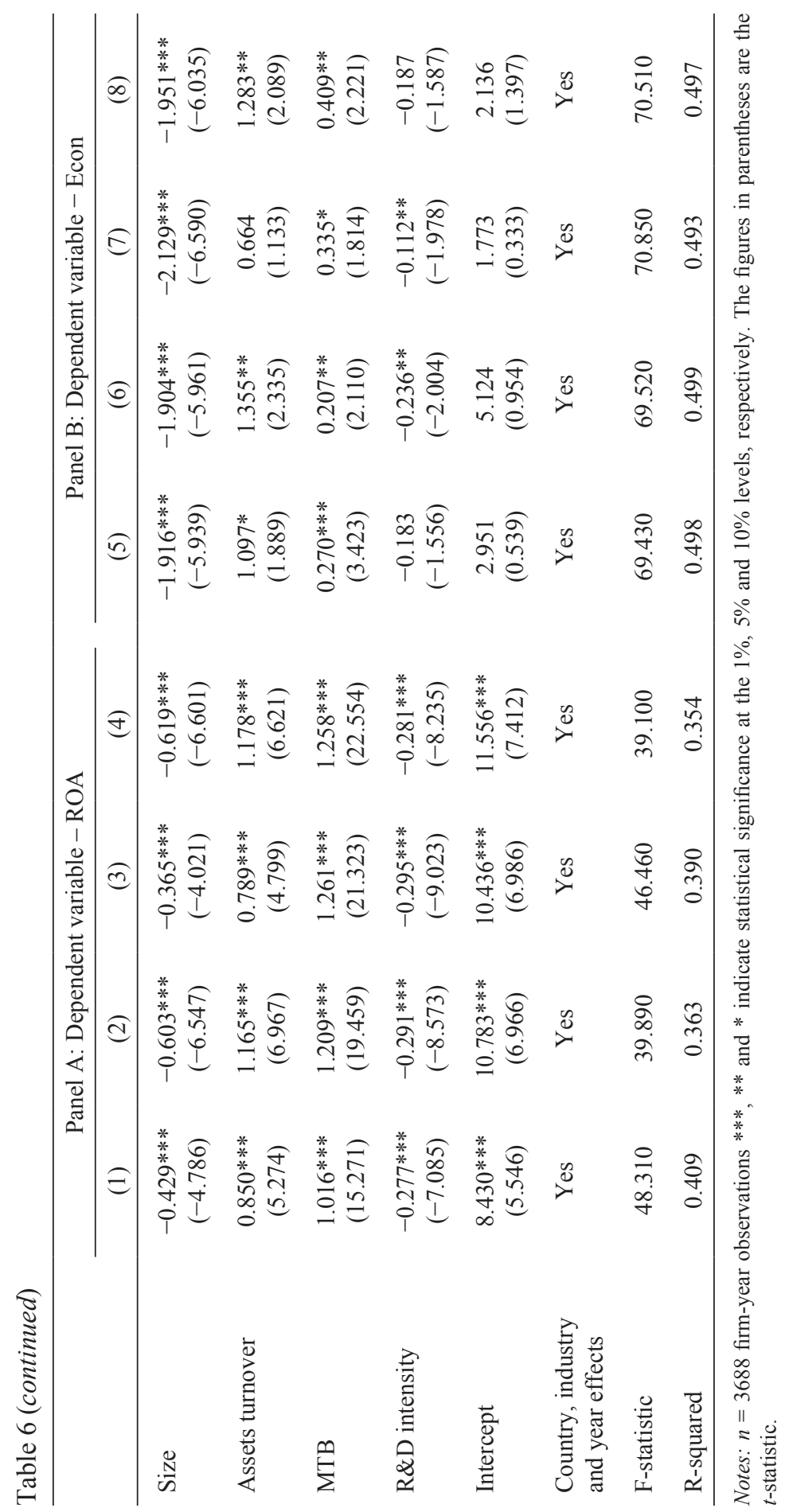


We further examine the effects of the interaction of individual elements of ESG and financial slack on Shariah firm performance. Columns 5 to 8 in Table 7 show that the coefficients of the interaction terms are not significant in moderating the relationship between the individual dimensions of ESG and firm performance. All in all, these results do not support the financial slack theory that when the level of financial slack is high, firms would engage in more ESG activities to improve firm performance. Therefore, our results in this section do not support H5. We interpret these results in light of the stakeholder theory in which ESG activities of firms are done because the management desire to promote socially responsible activities regardless of their financial slack situation. Our findings are in line with Ahmad (2000), who views that Islamic finance should strive to achieve a balance between providing sufficient return to their shareholders, while, at the same time, not neglecting their social responsibilities and commitment to their various other stakeholders.

\section{Granger Causality Analysis}

This study recognises the possibility of the endogeneity effect between ESG and performance. For example, ESG engagement may lead to higher performance; on the other hand, firms with higher performance are more likely to engage in ESG as they have more financial resources. Graves and Waddock (1994), and Hart and Ahuja (1996), among others, have used lagged ESG as an independent variable. In the previous sections, we have used lagged independent variables for the ESG performance for all the regression models. In this section, we perform the Granger causality test to determine if there is a two-way causality that can create an endogeneity problem. Following Wooldridge (2010, p. 650), two lags are typically used in calculating the Granger causality test in annual data.

Table 8 presents the results of the Granger causality test. Although the Panel A results indicate a unidirectional causality between aggregate ESG and $R O A$, we find a bidirectional relationship between aggregate ESG and Econ. Panel B reports the relationship between individual ESG elements and performance, and shows that, in general, there is a unidirectional relationship between the individual ESG dimension and firm performance. As for the environmental dimension, the Granger causality test indicates no significant impact on $R O A$, but a bidirectional relationship between the social dimension and Econ. The overall results seem to indicate a unidirectional causality between ESG and performance. The results suggest that, on average, a change in ESG has a positive impact on the change in firm performance. 
ESG Practices and Performance in Shariah Firms

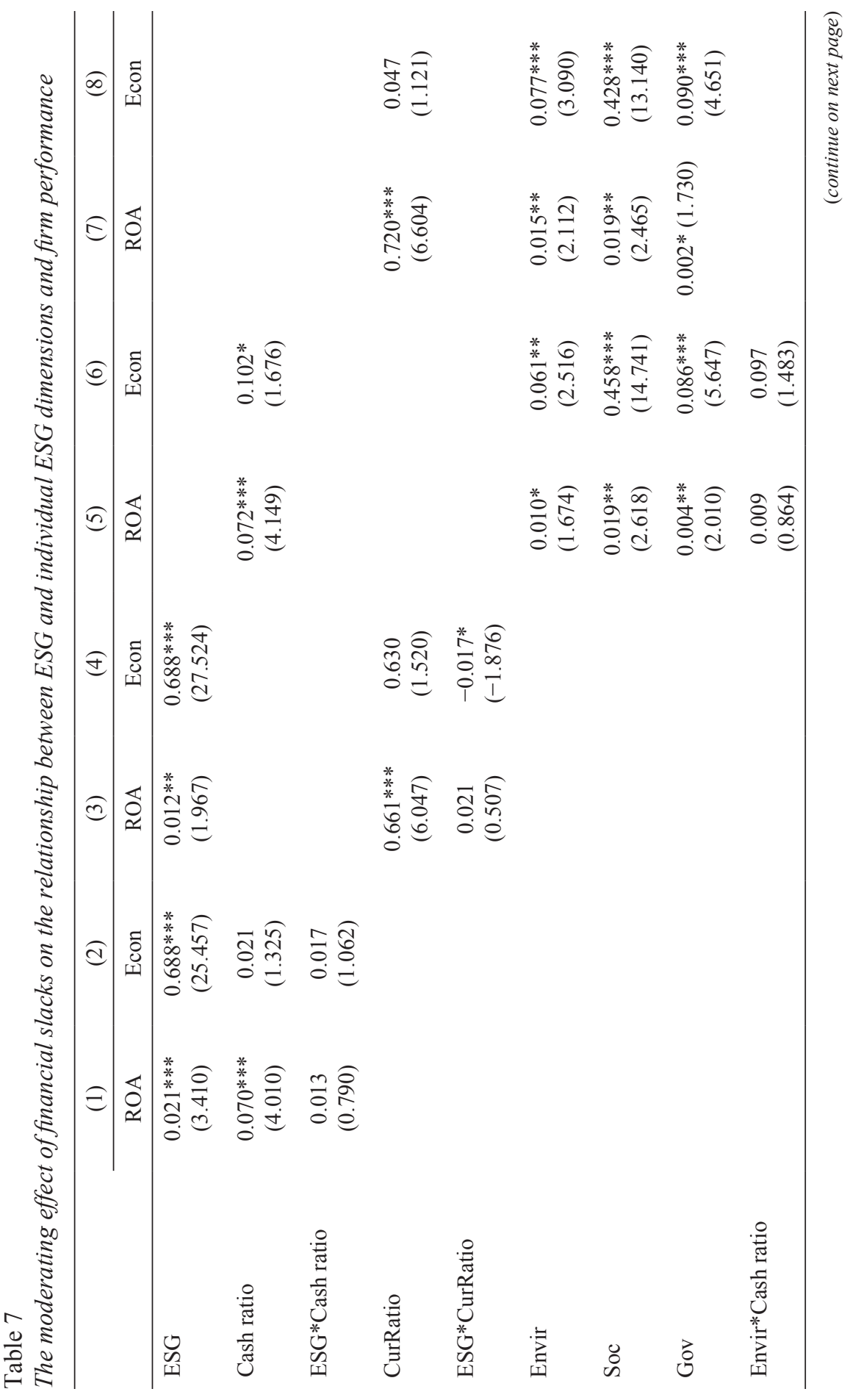


Lee Siew Peng and Mansor Isa

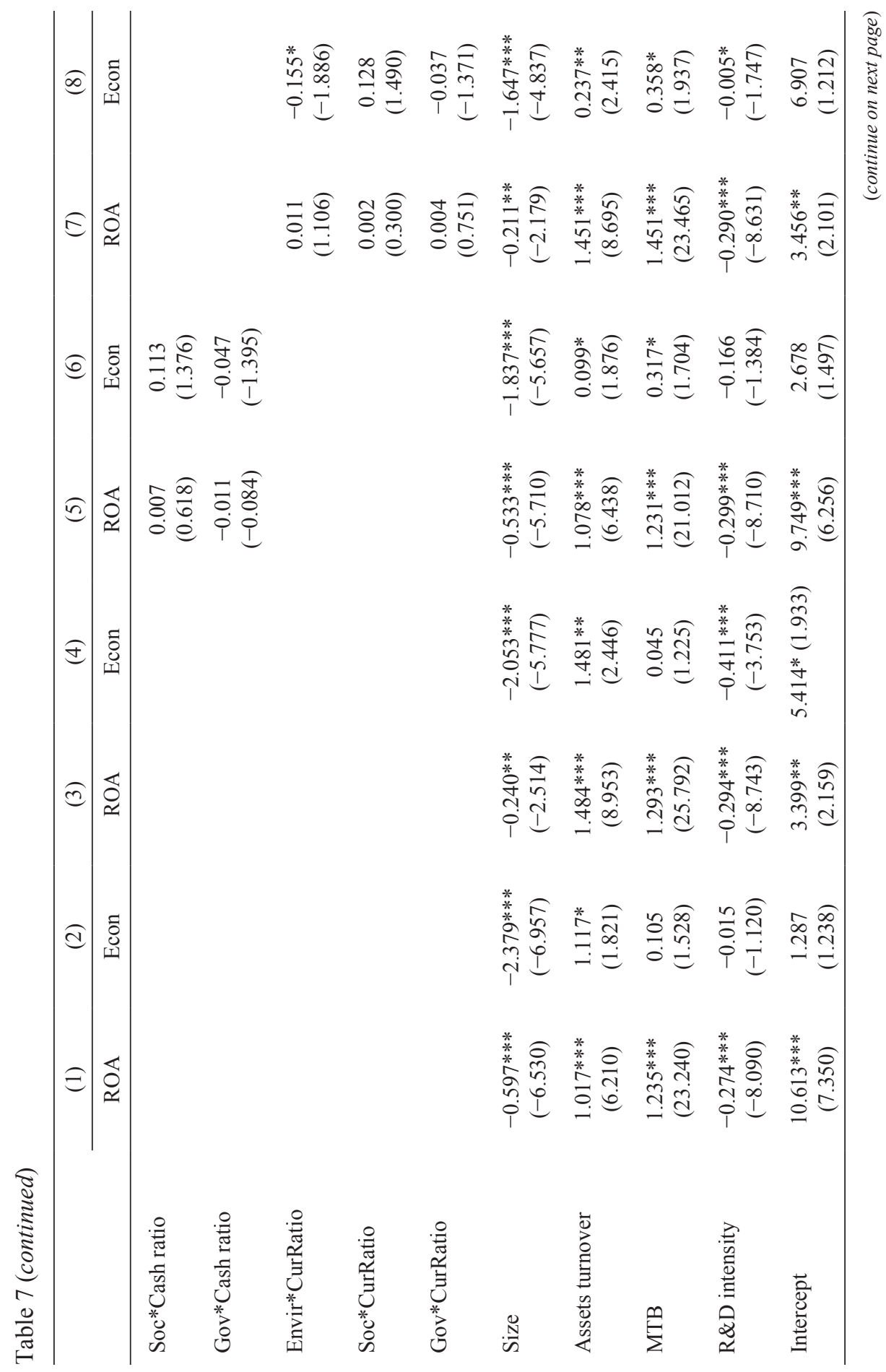




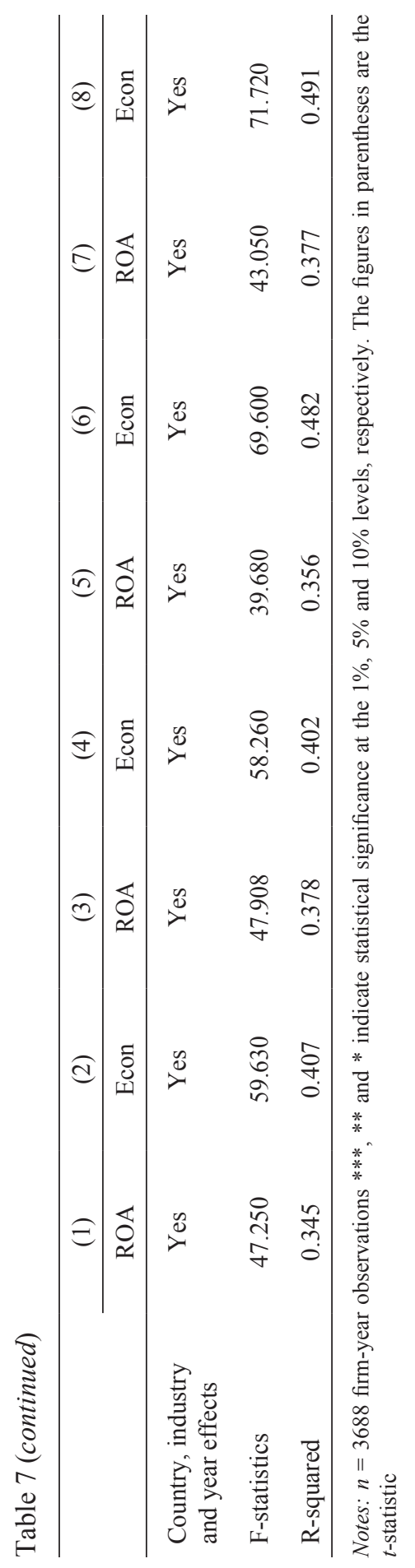


Table 8

Granger causality test

\begin{tabular}{|c|c|c|}
\hline Equation & $P$-value & $\begin{array}{l}\text { Relationship according to } \\
\text { Granger causality test }\end{array}$ \\
\hline \multicolumn{3}{|l|}{ Panel A: ESG } \\
\hline ESG does not Granger-cause ROA & $0.042 * *$ & Unidirectional \\
\hline ROA does not Granger-cause ESG & 0.156 & \\
\hline ESG does not Granger-cause Econ & $0.002 * * *$ & Bidirectional \\
\hline Econ does not Granger-cause ESG & $0.053 *$ & \\
\hline \multicolumn{3}{|l|}{ Panel B: Disaggregated ESG score } \\
\hline Environmental does not Granger-cause ROA & 0.824 & Independent \\
\hline ROA does not Granger-cause Environmental & 0.145 & \\
\hline Social does not Granger-cause ROA & $0.082 *$ & Unidirectional \\
\hline ROA does not Granger-cause Social & 0.960 & \\
\hline Governance does not Granger-cause ROA & $0.083^{*}$ & Unidirectional \\
\hline ROA does not Granger-cause Governance & 0.897 & \\
\hline Environmental does not Granger-cause Econ & $0.001 * * *$ & Unidirectional \\
\hline Econ does not Granger-cause Environmental & 0.194 & \\
\hline Social does not Granger-cause Econ & $0.001 * * *$ & Bidirectional \\
\hline Econ does not Granger-cause Social & $0.003 * * *$ & \\
\hline Governance does not Granger-cause Econ & $0.026^{* *}$ & Unidirectional \\
\hline ROA does not Granger-cause Governance & 0.169 & \\
\hline
\end{tabular}

Notes: $* * *, * *$ and $*$ indicate Granger causality test is statistical significant at $1 \%, 5 \%$ and $10 \%$ levels, respectively.

\section{CONCLUSION}

This study examines the impact of ESG (environmental, social and governance) practices on Shariah firm performance over the period 2010-2017. Our data consist of 461 Shariah-compliant firms from 20 countries, taken from the MSCI World Islamic Index firms. We also analyse whether ESG engagements are motivated by agency or stakeholder motives. The firms' involvement in ESG activities are obtained from the Thomson Reuters ASSET4 database. Our dataset is unique in the sense that it fulfils the double screening of Shariah-compliant and ESG involvement. Firm performance is proxied by return on assets $(R O A)$ and financial economic sustainability performance (Econ). 
We find that the ESG is positively associated with firm performance. This finding is also consistent for all three ESG individual elements - environmental, social and governance. Our results are similar for the two performance measures, i.e., ROA and Econ. Our results suggest that firms with good ESG practices increase performance, which is consistent with the stakeholder theory based on good management practices. Our results therefore reject the agency hypothesis. This implies that the Shariah firms in our study use ESG activities as part of their strategy to create value and to signal to stakeholders regarding their ESG commitment in the competitive market. The positive relationship between ESG and Econ performance suggests that these firms undertake ESG activities to generate sustainable growth.

The findings have a number of implications for managers, policymakers, and academicians. First, from the managerial perspective, this study provides evidence that combined ESG and Shariah-compliant screening does not impair firm performance. In fact, Shariah firms engaging in ESG activities are found to be improving their performance. This is important given the growth in the interest in Islamic finance and responsible finance. If Shariah firms incorporate ESG, they could jointly focus more on ethical (i.e., environmental impact activities), responsible and transparent practices; and managers can use ESG as a strategy to create new markets for potential investors. Second, the impact of ESG on Shariah firm performance is not due to their financial slack. This means it is the firms' conscious strategy to be involved in ESG due to their fiduciary obligations to their stakeholders and not due to the availability of internal resources. Therefore, policymakers should encourage Shariah firms to include universal environmental, social, and governance issues in their management practices. Third, this study presents new evidence on the impact of ESG practices on the performance of Shariah-compliant firms, thereby paving the way for further studies on sustainable development in Islamic finance.

\section{ACKNOWLEDGEMENTS}

This study was conducted while the corresponding author was a fellow at the Oxford Centre for Islamic Studies. The author is grateful to the Securities Commission Malaysia and Oxford Centre for Islamic Studies for giving her the opportunity to participate in the SC-OCIS Visiting Fellowship programme. 


\section{REFERENCES}

Ahmad, K. (2000). Islamic finance and banking: Challenges and prospects. Review of Islamic Economics, 9, 57-82.

Allouche, J., \& Laroche, P. (2005). A meta-analytical investigation of the relationship between corporate social and financial performance. Revue de Gestion des Ressources Humaines, 57(1), 18-41.

Barnea, A., \& Rubin, A., (2010). Corporate social responsibility as a conflict between shareholders. Journal of Business Ethics, 97(1), 71-86. https://doi.org/10.1007/ s10551-010-0496-z

Baron, D. P. (2008). Managerial contracting and corporate social responsibility. Journal of Public Economics, 92(1), 268-288. https://doi.org/10.1016/j.jpubeco.2007.05.008

Benabou, R., \& Tirole, J. (2010). Individual and corporate social responsibility. Econometrica, 77(305), 1-19. https://doi.org/10.1111/j.1468-0335.2009.00843.x

Borghesi, R., Houston, J., \& Naranjo, A. (2014). Corporate socially responsible investments: CEO altruism, reputation, and shareholder interest. Journal of Corporate Finance, 26(1), 164-181. https://doi.org/10.1016/j.jcorpfin.2014.03.008

Brooks, C. (2014). Introductory econometrics for finance (3rd ed.). Cambridge: Cambridge University Press. https://doi.org/10.1017/CBO9781139540872

Brown, W. O., Helland, E., \& Smith, J. K. (2006). Corporate philanthropic practices. Journal of Corporate Finance, 12(5), 855-877. https://doi.org/10.1016/j. jcorpfin.2006.02.001

Campbell, J. L. (2007). Why would corporations behave in socially responsible ways? An institutional theory of corporate social responsibility. Academy of Management Review, 32(3), 946-967. https://doi.org/10.5465/amr.2007.25275684

Charfeddine, L., Najah, A., \& Teulon, F. (2016). Socially responsible investing and Islamic funds: New perspectives for portfolio allocation. Research in International Business and Finance, 36, 351-361. https://doi.org/10.1016/j.ribaf.2015.09.031

Cheng, I. H., Hong, H., \& Shue, K. (2013). Do managers do good with other peoples' money? Working paper, Dartmouth College, Princeton University, and University of Chicago. https://doi.org/10.3386/w19432

Deng, X., Kang, J. K., \& Low, B. (2013). Corporate social responsibility and stakeholder value maximization: Evidence from mergers. Journal of Financial Economics, 110(1), 87-109. https://doi.org/10.1016/j.jineco.2013.04.014

Dhaliwal, D. S., Li, O. Z., Tsang, A., \& Yang, Y. G. (2011). Voluntary nonfinancial disclosure and the cost of equity capital: The initiation of corporate social responsibility reporting. The Accounting Review, 86(1), 59-100. https://doi. org/10.2308/accr.00000005

Dusuki, A. W. (2008). What does Islam say about corporate social responsibility? Review of Islamic Economics, 12(1), 5-28.

Duuren, E. V., Plantinga, A., \& Scholtens, B. (2016). ESG Integration and the investment management process: Fundamental investing reinvented. Journal of Business Ethics, 138(3), 525-533. https://doi.org/10.1007/s10551-015-2610-8 
Edmans, A. (2011). Does the stock market fully value intangibles? Employee satisfaction and equity prices. Journal of Financial Economics, 101(3), 621-640. https://doi.org/10.1016/j.jfineco.2011.03.021

El Ghoul, S., Guedhami, O., \& Kim, Y. T. (2017). Country-level institutions, firm value, and the role of corporate social responsibility initiatives. Journal of International Business Studies, 48(3), 360-385. https://doi.org/10.1057/jibs.2016.4

Erragragui, E., \& Revelli, C. (2016). Is it costly to be both shariah compliant and social responsible? Review of Financial Economics, 31, 64-74. https://doi.org/10.1016/j. rfe.2016.08.003

Fatemi, A., Glaum, M., \& Kaiser, S. (2018). ESG performance and firm value: The moderating role of disclosure. Global Finance Journal, 38, 45-64. https://doi.org/10.1016/j.gfj.2017.03.001

Ferreira, M. A., \& Laux, P. A. (2007). Corporate governance, idiosyncratic risk, and information flow. Journal of Finance, 62(2), 951-989. https://doi.org/10.1111/ j.1540-6261.2007.01228.x

Ferrell, A., Liang, H., \& Renneboog, L. (2016). Socially responsible firms. Journal of Financial Economics, 122(3), 585-606. https://doi.org/10.1016/j. jfineco.2015.12.003

Freeman, R. (1994). The politics of stakeholder theory: Some future directions. Business Ethics Quarterly, 4(4), 409-421. https://doi.org/10.2307/3857340

Friedman, M. (1970). The social responsibility of business is to increase its profits. New York Time Magazine, 32-33, September 13.

Governance and Accountability Institute (2017). SP500 companies published corporateSustainability reports 2016. New York, NY: Governance and Accounting Institute, Inc.

Graves, S. B., \& Waddock, S. A. (1994). Institutional owners and corporate social performance. Academy of Management Journal, 37(4), 1034-1046. https://doi. org/10.5465/256611

Halbritter, G., \& Dorfleitner, G. (2015). The wages of social responsibility - where are they? A critical review of ESG investing. Review of Financial Economics, 26, 25-35. https://doi.org/10.1016/j.rfe.2015.03.004

Hart, S. L., \& Ahuja, G. (1996). Does it pay to be green? An empirical examination of the relationship between emission reduction and firm Performance. Business Strategy and the Environment, 5(1), 30-37. https://oi.org/10.1002/(SICI)10990836(199603)5:1\%3C30::AID-BSE38\%3E3.0.CO;2-Q

Hou, T. C. T. (2019). The relationship between corporate social responsibility and sustainable financial performance: Firm-level evidence from Taiwan. Corporate Social Responsibility and Environmental Management, 26(1), 19-28. https://doi. org/10.1002/csr.1647

Jensen, M. C. (1986). Agency costs of free cash flow, corporate finance, and takeovers. American Economic Review, 76(2), 323-329.

Jensen, M. C. (2002). Value maximization, stakeholder theory and the corporate objective function. Business Ethics Quarterly, 12(2), 235-256. https://doi. org $/ 10.2307 / 3857812$ 
Jensen, M. C., \& Meckling, W. H. (1976). Theory of the firm: Managerial behavior, agency costs and ownership structure. Journal of Financial Economics, 3(4), 305-360.

Jitmaneeroj, B. (2016). Reform priorities for corporate sustainability: Environmental, social, governance or economic performance? Management Decision, 54(6), 1496-1521. https://doi.org/10.1108/MD-11-2015-0505

Jo, J., \& Harjoto, M. A. (2012). The causal effect of corporate governance on corporate social responsibility. Journal of Business Ethics, 106(1), 53-72. https://doi.org/10.1007/s10551-011-1052-1

Kao, E. H., Yeh, C. C., Wang, L. H., \& Fung, H. G. (2018). The relationship between CSR and performance: Evidence in China. Pacific-Basin Finance Journal, 51, 155-170. https://doi.org/10.1016/j.pacfin.2018.04.006

Kraatz, M. S., \& Zajac, E. J. (2001). How organizational resources affect strategic change and performance in turbulent environments: Theory and evidence. Organization Science, 12(5), 632-657. https://doi.org/10.1287/orsc.12.5.632.10088

Kruger, P. (2015). Corporate goodness and shareholder wealth. Journal of Financial Economics, 115(2), 304-325. https://doi.org/10.1016/j.jfineco.2014.09.008

La Porta, R., Lopez-de-Silanes, F., Shleifer, A., \& Vishny, R. (2000). Agency problems and dividend policies around the world. Journal of Finance, 55(1), 1-33. https://doi.org/10.1111/0022-1082.00199

Lee, D., \& Faff, R. (2009). Corporate sustainability performance and idiosyncratic risk: A global perspective. The Financial Review, 44(2), 213-237. https://doi. org/10.1111/j.1540-6288.2009.00216.X

Lee, D. D., Faff, R. W., \& Rekker, S. A. (2013). Do high and low-ranked sustainability stocks perform differently? International Journal of Accounting and Information Management, 21(2), 116-132. https://doi.org/10.1108/18347641311312267

Li, D. Y., Cao, C. C., Zhang, L., Chen, X. H., Ren, S. G., \& Zhao, Y. N. (2017). Effects of corporate environmental responsibility on financial performance: The moderating role of government regulation and organizational slack. Journal of Cleaner Production, 166, 1323-1334. https://doi.org/10.1016/j.jclepro.2017.08.129

Li, Y. W., Gong, M. F., Zhang, X. Y., \& Koh, L. (2018). The impact of environmental, social, and governance disclosure on firm value: The role of CEO power. The British Accounting Review, 50(1), 60-75. https://doi.org/10.1016/j.bar.2017.09.007

Lu, W., Chau, K. W., Wang, H., \& Pan, W. (2014). A decade's debate on the nexus between corporate social and corporate financial performance: A critical review of empirical studies 2002-2011. Journal of Cleaner Production, 79, 195-206. https://doi.org/10.1016/j.jclepro.2014.04.072

Masulis, R., Wang, C., \& Xie, F. (2009). Agency problems at dual-class companies. Journal of Finance, 64(4), 1697-1727. https://doi.org/10.1111/j.1540-6261 .2009.01477.x

Masulis, R. W., \& Reza, S. W. (2015). Agency problem of corporate philanthropy. The Review of Financial Studies, 28(2), 592-636. https://doi.org/10.1093/rfs/hhu082

Mattingly, J. E., \& Olsen, L. (2018). Performance outcomes of investing slack resources in corporate social responsibility. Journal of Leadership \& Organizational Studies, 25(4), 481-498. https://doi.org/10.1177/1548051818762336 
Morck, R., \& Yeung, B. (2005). Dividend taxation and corporate governance. Journal of Economic Perspectives, 19(3), 163-180. https://doi.org/10.1257/ 089533005774357752

MSCI Islamic Index Series Methodology (2017). Retrieved October 2019, from http://www.msci.com/eqb/methodology/meth_docs/MSCI_Sep17_Islamic_ Indexes_Methodology.pdf

Ng, A. C. \& Rezaee, Z. (2015). Business sustainability performance and cost of equity capital. Journal of Corporate Finance, 34, 128-149. https://doi.org/10.1016/j. jcorpfin.2015.08.003

Nollet, J., Filis, G., \& Mitrokostas, E. (2016). Corporate social responsibility and financial performance: A non-linear and disaggregated approach. Economic Modelling. 52(B), 400- 407. https://doi.org/10.1016/j.econmod.2015.09.019

Odell, J., \& Ali, U. (2016). ESG investing in emerging and frontier markets. Journal of Applied Corporate Finance, 28(2), 96-101.

Qi, G. Y., Zeng, S. X., Shi, J. J., Meng, X. H., Lin, H., \& Yang, Q. X. (2014). Revisiting the relationship between environmental and financial performance in Chinese industry. Journal of Environmental Management, 145, 349-356. https://doi. org/10.1016/j.jenvman.2014.07.010

Schuler, D. A., \& Cording, M. (2006). A corporate social performance-corporate financial performance behavioral model for consumers. Academy of Management Review, 31(3), 540-558. https://doi.org/10.5465/amr.2006.21318916

Seifert, B., Morris, S. A., \& Bartkus, B. R. (2004). Having, giving, and getting: Slack resources, corporate philanthropy, and firm financial performance. Business \& Society, 43(2), 135-161. https://doi.org/10.1177/0007650304263919

Servaes, H., \& Tamayo, A. (2014). How do industrial peers respond to control threat? Management Science, 60(2), 380-399. https://doi.org/10.1287/mnsc.2013.1773

Tan, S. H., Habibullah, M. S., Tan, S. K., \& Choon, S. W. (2017). The impact of the dimensions of environmental performance on firm performance in travel and tourism industry. Journal of Environmental Management, 1(1), 603-611. https://doi.org/10.1016/j.jenvman.2017.02.029

Thomson Reuters ESG Scores. (2017). Retrieved October 2019, from https://www.esade. edu/itemsweb/biblioteca/bbdd/inbbdd/archivos/Thomson_Reuters_ESG_Scores. pdf

Thomson Reuters Islamic Banking and Finance Summit. (2010). Retrieved from http:// www.customers.reuters.com/wetfetch/index.aspx $?$ CID $=30887 \&$ doc $=$ Reuters Islamic_Banking_and_Finance_Summit_10.pdf\&base $=/$ community/summits/ previous.asp

Verheyden, T., Eccles, R. G., \& Feiner, A. (2016). ESG for all? The impact of ESG screening on return, risk, and diversification. Journal of Applied Corporate Finance, 28(2), 47-55.

Wang, Z., \& Sarkis, J. (2017). Corporate social responsibility governance, outcomes, and financial performance. Journal of Cleaner Production, 162, 1607-1616. https://doi.org/10.1016/j.jclepro.2017.06.142 
Lee Siew Peng and Mansor Isa

Wooldridge, J. M. (2010). Econometric analysis of cross section and panel data. Cambridge: MIT Press.

Zhang, Y., Li, J., Jiang, W.X., Zhang, H. M., Hu, Y. H., \& Liu, M. (2018). Organizational structure, slack resources and sustainable corporate socially responsible performance. Corporate Social Responsibility and Environmental Management, 25(6), 1099-1107. https://doi.org/10.1002/csr.1524 